JA: Jurnal Al-Wasath 2 No.2: 63-74

Journal homepage: https://journal.unusia.ac.id/index.php/alwasath/index

ISSN 2721-6160 (Online)

\section{Analisis Kesesuaian Pengaturan Badan Usaha Milik Desa dengan Nilai-Nilai Pancasila}

\section{Allan Fatchan Gani Wardhana}

Universitas Islam Indonesia

\begin{abstract}
Abstrak
Desa sebagai entitas hukum memiliki kewenangan lebih untuk mengatur dan mengelola urusan wilayahnya secara otonom, salah satunya membentuk Badan Usaha Milik Desa (BUM Desa). BUMDesa menjadi salah satu modal penting bagi desa untuk mewujudkan pemberdayaan masyarakat dan harus dikelola dengan semangat kekeluargaan dan kegotongroyongan. Penelitian ini mengkaji dua hal, pertama bagaimana pengaturan BUMDesa dalam peraturan perundang-undangan, kedua apakah pengaturan mengenai BUMDesa sudah berkesesuaian dengan nilai-nilai Pancasila. Penelitian ini menggunakan metode yuridis normatif dengan pendekatan perundangundangan. Hasil penelitian menyimpulkan bahwa Pengaturan BUM Desa diatur dalam 3 (tiga) level peraturan perundang-undangan (Undang-Undang, Peraturan Pemerintah, dan Peraturan Menteri). Pengaturan yang sangat komprehensif justru diatur dalam level Peraturan Menteri. BUM Desa merupakan pilar dan tonggak yang dapat mendorong kemajuan desa sehingga hal-hal penting sudah seharusnya diatur dalam level UndangUndang, Kedua, Pengaturan BUM Desa dalam berbagai regulasi secara normatif sudah berkesuaian dengan nilai-nilai Pancasila yaitu sila kemanusiaan, persatuan, kerakyatan, dan keadilan sudah dijadikan sebagai landasan dalam pendirian, pengelolaan, pengembangan, dan pemanfaatan hasil usaha BUM Desa.
\end{abstract}

\section{Keywords:}

Pengaturan, BUMDesa, Pancasila

\section{Corresponding Author:}

Allan Fatchan Gani Wardhana

Universitas Islam Indonesia

Email: allanfgwardhana@uii.ac.id

(C) The Author(s) 2022

DOI: $10.47776 /$ alwasath.v2i2.180

\section{Classification \\ Conceptual Article}

Submitted: 29 April 2021

Accepted: 12 Oktober 2021

Online: 13 Oktober 2021

CC BY: This license allows reusers to distribute, remix, adapt, and build upon the material in any medium or format, so long as attribution is given to the creator. The license allows for commercial use. 


\section{PENDAHULUAN}

Secara vertikal, Indonesia mempunyai struktur pemerintahan yang unik. Keunikan ini pada struktur pemerintahan yang terendah yaitu tingkat desa. Meskipun dilihat dari struktur vertikal merupakan pemerintahan terendah, namun keberadaan Desa tidak dapat diabaikan begitu saja. Kedudukan Desa menjadi sangat penting dalam konteks Indonesia, sebab Desa mempunyai konstribusi baik secara ekonomi, sosial, maupun sumber daya yang tidak sedikit dalam pembangunan negara ${ }^{1}$.Konsep desa sebagai entitas sosial memiliki berbagai bentuk, tergantung perspektif apa yang hendak digunakan untuk melihat desa tersebut. Namun secara umum, desa tidak saja dapat didefinisikan sebagai kesatuan masyarakat hukum yang memiliki batas-batas wilayah dan berwenang dalam mengatur, mengurus segala kebutuhan, kepentingan masyarakat setempat yang diakui serta dihormati keberadaannya dalam sistem pemerintahan Negara Kesatuan Republik Indonesia (NKRI), akan tetapi desa sebagai kesatuan masyarakat hukum memberikan pemahaman bahwa institusi desa bukan hanya sebagai entitas administratif (administrative entity), melainkan juga sebagai entitas hukum (legal entity) yang secara tidak langsung juga harus dihargai, diistimewakan dan dilindungi dalam sistem pemerintahan di Indonesia ${ }^{2}$.

Seiring dengan berkembangnya kebutuhan masyarakat, politik hukum pemerintahan desa mengalami perubahan yang mendasar. Pemerintah mulai menyadari pentingnya desa dalam membangun dan menguatkan Negara Kesatuan Republik Indonesia (NKRI). Sehingga pada tahun 2014, Undang-Undang Nomor 6 Tahun 2014 tentang Desa (UU Desa) pun lahir sebagai landasan hukum baru bagi penyelenggaraan pemerintahan desa. Dengan lahirnya UU Desa, masyarakat di desa telah mendapatkan payung hukum yang lebih kuat dibandingkan pengaturan desa di dalam Undang-Undang Nomor 22 Tahun 1999 maupun Undang-Undang Nomor 32 Tahun 2004 tentang Pemerintahan Daerah. ${ }^{3}$ Melalui UU Desa tersebut, desa sebagai entitas hukum (legal entity) memiliki kewenangan lebih untuk mengatur dan mengelola urusan wilayahnya secara otonom, salah satunya membentuk Badan Usaha Milik Desa (BUM Desa).

Melalui UU Nomor 6 Tahun 2014 tersebut, desa sebagai entitas hukum (legal entity) memiliki kewenangan lebih untuk mengatur dan mengelola urusan wilayahnya secara otonom. Salah satu kewenangan yang sangat penting yaitu merancang dan menetapkan Peraturan Desa (Perdes). Dalam Pasal 1 angka (7) UU Nomor 6 Tahun 2014, Peraturan Desa adalah peraturan perundang-undangan yang ditetapkan oleh Kepala Desa setelah dibahas dan disepakati bersama Badan Permusyawaratan Desa. Dalam UU Nomor 6 Tahun 2014, Perdes digunakan untuk mengatur antara lain tentang Anggaran Pendapatan dan Belanja Desa (APBD); Rencana Pembangunan Jangka Menengah Desa dan Rencana Kerja Pemerintah Desa; dan Pendirian Badan Usaha Milik Desa (BUMDesa). Oleh karena itu Perdes merupakan hal yang turut menentukan penyelenggaraan pemerintahan desa. Tentu saja bahwa dalam penyelenggaran pemerintahan desa harus ada partisipasi aktif dari masyarakat, sehingga kebutuhan masyarakat dapat diakomodasi dengan baik oleh pemerintah desa. Hal ini tentunya sejalan dengan keberadaan desa sebagai self governing communities yang bersifat otonom dan mandiri ${ }^{4}$.Adanya Perdes dan partisipasi masyarakat dalam penyelenggaraan pemerintahan desa merupakan wujud dari kehidupan masyarakat desa yang merupakan bentuk komunitas yang dapat mengurus dirinya sendiri ${ }^{5}$.

Terkait dengan keberadaan BUMDesa, tentu ini menjadi salah satu modal penting bagi desa untuk mewujudkan pemberdayaan masyarakat. Desa akan sejahtera dan mandiri antara lain karena keberadaan dan pengelolaan potensi desa melalui BUMDes yang optimal dan efektif. Dalam implementasinya, pemerintah kabupaten/kota menetapkan peraturan daerah (perda) tentang

\footnotetext{
${ }^{1}$ Sri Hastuti Puspitasari, Menuju Kemandirian Desa Melalui Undang-Undang Nomor 6 Tahun 2014 Tentang Desa, FH UII, Yogyakarta, 2017, hlm. 1

2 Ateng Syafrudin dan Suprin Na’a, Republik Desa, Pergulatan Hukum Tradisional dan Hukum Modern dalam Desain Otonomi Daerah, Alumni, Bandung, 2010, hlm.3-4

${ }^{3}$ Ni'matul Huda, Hukum Pemerintahan Desa Dalam Konstitusi Indonesia Sejak Kemerdekaan Hingga Era Reformasi, Setara Press, Malang, 2015, hlm. 206.

${ }^{4}$ Jimly Ashhiddiqie, Konstitusi Dan Konstitusionalisme Indonesia, Sinar Grafika, Jakarta, 2011, hlm. 242.

5 Jimly Asshiddiqie, Pengantar Ilmu Hukum Tata Negara. Cet 3, Rajawali Press, Jakarta, 2011, hlm. 179.
} 
pedoman tata cara pembentukan dan pengelolaan BUMDesa. Ketentuan ini bersifat mandatory, bukan voluntary sehingga pengelolaan BUMDesa sesuai dengan karakteristik wilayah masing-masing 6 .

Penelitian ini akan menguraikan mengenai dua hal, pertama mengenai bagaimana pengaturan BUMDesa dalam peraturan perundang-undangan, kedua apakah pengaturan mengenai BUMDesa sudah berkesesuaian dengan nilai-nilai Pancasila. Dari latar belakang tersebut di atas penulis mengajukan rumusan permasalahan sebagai berikut, 1) Bagaimana Badan Usaha Milik Desa dalam Peraturan Perundang-Undangan? 2) Kesesuaian Pengaturan Badan Usaha Milik Desa dengan Nilai-Nilai Pancasila?

\section{METODOLOGI PENELITIAN}

Metode yang digunakan dalam penelitian ini yaitu metode yuridis normatif dengan menggunakan data sekunder yang diperoleh dari hasil studi kepustakaan (library research). Bahan penelitian ini menggunakan bahan hukum primer dan sekunder. Bahan hukum primer yang digunakan adalah Undang-Undang nomor 6 Tahun 2014 tentang Desa, Undang-Undang Nomor 11 Tahun 2020 tentang Cipta Kerja, Peraturan Pemerintah Nomor 43 Tahun 2014 tentang Pelaksanaan UU Desa dan Peraturan Menteri Desa, Pembangunan Daerah Tertinggal, dan Transmigrasi Nomor 4 Tahun 2015 tentang Pendirian, Pengurusan, dan Pengelolaan, dan pembubaran Badan Usaha Milik Desa. Metode analisis yang digunakan dalam penelitian ini ialah analisis deskriptif-kualitatif dengan metode pendekatan peraturan perundang-undangan (statute approach).

\section{HASIL DAN PEMBAHASAN}

\section{Pengaturan Badan Usaha Milik Desa dalam Peraturan Perundang-Undangan}

Dalam UU Desa, pembentukan dan pendirian BUM Desa ditegaskan harus melalui Peraturan Desa. Oleh karena itu Perdes merupakan hal yang turut menentukan penyelenggaraan pemerintahan desa terutama dalam mengembangkan BUM Desa. Hal ini tentunya sejalan dengan keberadaan desa sebagai self governing communities yang bersifat otonom dan mandiri. Dengan kehadiran BUM Desa diharapkan desa akan menjadi lebih mandiri dan masyarakat semakin sejahtera $^{7}$. Pasal 1 angka (6) UU Desa mendefinisikan bahwa Badan Usaha Milik Desa yang selanjutnya disebut BUM Desa, adalah badan usaha yang seluruh atau sebagian besar modalnya dimiliki oleh Desa melalui penyertaan secara langsung yang berasal dari kekayaan Desa yang dipisahkan guna mengelola aset, jasa pelayanan, dan usaha lainnya untuk sebesar-besarnya kesejahteraan masyarakat Desa.

Adapun salah satu yang dapat dimuat dalam Peraturan Desa ialah terkait Dalam Pasal 87 ayat (1) ditegaskan bahwa Desa dapat mendirikan Badan Usaha Milik Desa yang disebut BUMDesa. Pada ayat (2) dijelaskan bahwa BUM Desa dikelola dengan semangat kekeluargaan dan kegotongroyongan dan ayat (3) BUM Desa dapat menjalankan usaha di bidang ekonomi dan/atau pelayanan umum sesuai dengan ketentuan peraturan perundang-undangan. Pasal 88 ayat (1) dan ayat (2) mengatur bahwa pendirian BUMDesa disepakati melalui Musyawarah Desa dan ditetapkan dengan Peraturan Desa. Sesuai dengan Pasal 89, hasil dari usaha BUMDesa dapat dimanfaatkan untuk pengembangan usaha; dan Pembangunan Desa, pemberdayaan masyarakat Desa, dan pemberian bantuan untuk masyarakat miskin melalui hibah, bantuan sosial, dan kegiatan dana bergulir yang ditetapkan dalam Anggaran Pendapatan dan Belanja Desa.

Penjelasan Pasal 87 UU Desa menegaskan bahwa BUM Desa dibentuk oleh Pemerintah Desa untuk mendayagunakan segala potensi ekonomi, kelembagaan perekonomian, serta potensi sumber daya alam dan sumber daya manusia dalam rangka meningkatkan kesejahteraan masyarakat

\footnotetext{
${ }^{6} \mathrm{https}$ //www.wartaekonomi.co.id/read231487/mendorong-pengelolaan-bumdesa-secara-profesional (diakses 13 April 2021)

${ }^{7}$ Kementerian Desa, Pembangunan Daerah Tertinggal dan Transmigrasi Republik Indonesia, Modul KKN Tematik Desa Membangun Badan Usaha Milik Desa (BUM Desa), Jakarta, 2019, hlm. 3
} 
Desa. Dalam meningkatkan sumber pendapatan Desa, BUM Desa dapat menghimpun tabungan dalam skala lokal masyarakat Desa, antara lain melalui pengelolaan dana bergulir dan simpan pinjam. BUM Desa dalam kegiatannya tidak hanya berorientasi pada keuntungan keuangan, tetapi juga berorientasi untuk mendukung peningkatan kesejahteraan masyarakat Desa. BUM Desa diharapkan dapat mengembangkan unit usaha dalam mendayagunakan potensi ekonomi. Dalam hal kegiatan usaha dapat berjalan dan berkembang dengan baik, sangat dimungkinkan pada saatnya BUM Desa mengikuti badan hukum yang telah ditetapkan dalam ketentuan peraturan perundangundangan. Pengaturan mengenai Badan Usaha Milik Desa dalam UU Desa dapat dijelaskan secara rinci sebagai berikut:

\begin{tabular}{|c|c|c|}
\hline No & Pasal & Pengaturan \\
\hline 1 & $\begin{array}{lll}\text { Pasal } & 1 & \text { Definisi } \\
\text { angka (6) } & & \end{array}$ & $\begin{array}{l}\text { BUM Desa adalah badan usaha yang seluruh atau } \\
\text { sebagian besar modalnya dimiliki oleh Desa melalui } \\
\text { penyertaan secara langsung yang berasal dari } \\
\text { kekayaan Desa yang dipisahkan guna mengelola aset, } \\
\text { jasa pelayanan, dan usaha lainnya untuk sebesar- } \\
\text { besarnya kesejahteraan masyarakat Desa. }\end{array}$ \\
\hline
\end{tabular}

Ada perubahan terhadap definisi BUM Desa dalam Undang-Undang Nomor 11 Tahun 2020 tentang Cipta Kerja, yaitu "BUM Desa adalah Badan Hukum yang didirikan oleh desa dan/atau bersama desadesa guna mengelola usaha, memanfaatkan, aset, mengembangkan investasi dan produktivitas, menyediakan jasa pelayanan, dan/atau menyediakan jenis usaha lainnya untuk sebesar-besarnya kesejahteraan masyarakat Desa.

\begin{tabular}{rll}
\hline Pasal 87 Pengelolaan BUM & BUM Desa dikelola dengan semangat kekeluargaan \\
Desa & dan kegotongroyongan. Adapun BUM Desa dapat \\
& menjalankan usaha di bidang ekonomi dan/atau \\
pelayanan umum sesuai dengan ketentuan peraturan & perundang-undangan. \\
& Dalam Undang-Undang Nomor 11 Tahun 2020 \\
& tentang Cipta Kerja (Pasal 87) terdapat penegasan \\
& bahwa BUM desa dapat membentuk unit usaha \\
& berbadan hukum sesuai dengan kebutuhan dan \\
& tujuan. Dalam penjelasan pasal ini, diatur "Dalam \\
& rangka keterpaduan pembangunan daerah, BUM \\
& Desa dan unit usaha dibawahnya dalam \\
& menjalankan kegiatan usaha harus sesuai dengan \\
& rencana induk pembangunan daerah"
\end{tabular}

3 Penjelasan Status BUMDesa Pasal 87 ayat (1)
BUM Desa secara spesifik tidak dapat disamakan dengan badan hukum seperti perseroan terbatas, $\mathrm{CV}$, atau koperasi. Oleh karena itu, BUM Desa merupakan suatu badan usaha bercirikan Desa yang dalam pelaksanaan kegiatannya di samping untuk 


\begin{tabular}{|c|c|c|c|}
\hline & & & $\begin{array}{l}\text { membantu penyelenggaraan Pemerintahan Desa, } \\
\text { juga untuk memenuhi kebutuhan masyarakat Desa. }\end{array}$ \\
\hline 4 & $\begin{array}{l}\text { Penjelasan } \\
\text { Pasal } 87 \\
\text { ayat (1) }\end{array}$ & Fungsi BUMDesa & $\begin{array}{l}\text { BUM Desa juga dapat melaksanakan fungsi } \\
\text { pelayanan jasa, perdagangan, dan pengembangan } \\
\text { ekonomi lainnya. }\end{array}$ \\
\hline 5 & $\begin{array}{l}\text { Pasal } 88 \text { jo } \\
\text { Pasal } 54\end{array}$ & $\begin{array}{l}\text { Pendirian } \quad \text { BUM } \\
\text { Desa }\end{array}$ & $\begin{array}{l}\text { Pendirian BUM Desa disepakati melalui } \\
\text { Musyawarah Desa dan ditetapkan dengan Peraturan } \\
\text { Desa. }\end{array}$ \\
\hline 6 & Pasal 89 & $\begin{array}{l}\text { Pemanfaatan Hasil } \\
\text { Usaha }\end{array}$ & $\begin{array}{l}\text { Hasil usaha digunakan untuk pengembangan usaha; } \\
\text { dan Pembangunan Desa, pemberdayaan masyarakat } \\
\text { Desa, dan pemberian bantuan untuk masyarakat } \\
\text { miskin melalui hibah, bantuan sosial, dan kegiatan } \\
\text { dana bergulir yang ditetapkan dalam Anggaran } \\
\text { Pendapatan dan Belanja Desa. }\end{array}$ \\
\hline 7 & Pasal 90 & $\begin{array}{l}\text { Pengembangan } \\
\text { BUM desa }\end{array}$ & $\begin{array}{l}\text { Kolaborasi Pemerintah, Pemerintah Daerah Provinsi, } \\
\text { Pemerintah Daerah Kabupaten/Kota, dan Pemerintah } \\
\text { Desa } \\
\text { mendorong perkembangan BUM Desa dengan: a. } \\
\text { memberikan hibah dan/atau akses permodalan; } \\
\text { b.melakukan pendampingan teknis dan akses ke } \\
\text { pasar; dan c. memprioritaskan BUM Desa dalam } \\
\text { pengelolaan sumber daya alam di Desa. }\end{array}$ \\
\hline
\end{tabular}

\begin{tabular}{rllrl}
\hline $8 \quad$ Pasal & 92 & BUM Desa dalam & Kerja sama antar-Desa antara lain melalui \\
ayat (6) & Kerjasama antar & pengembangan usaha bersama yang dimiliki oleh \\
& Desa & & Desa untuk mencapai nilai ekonomi yang berdaya \\
& & saing. Untuk mewujudkan hal tersebut dilaksanakan \\
& & & dalam pelayanan usaha antar-Desa yang kemudian \\
& & dapat dibentuk BUM Desa yang merupakan milik 2 \\
& & (dua) Desa atau lebih.
\end{tabular}

9 Pasal 112 Fasilitasi petunjuk Pemerintah, Pemerintah Provinsi, Pemerintah teknis BUM Desa Kabupaten/Kota melakukan pembinaan yang dilakukan melalui program menyusun dan memfasilitasi petunjuk teknis bagi BUM Desa.

\begin{tabular}{llll}
\hline 10 & Pasal 113 & $\begin{array}{l}\text { Peran Pemerintah } \\
\text { Provinsi }\end{array}$ & Membina dan mengawasi penetapan pengaturan \\
& & BUM Desa Kabupaten/Kota.
\end{tabular}

\begin{tabular}{lll}
\hline 11 & Pasal 114 & $\begin{array}{l}\text { Peran Pemerintah } \\
\text { Kabupaten/Kota }\end{array}$
\end{tabular}

Selain diatur dalam UU Desa, pengaturan UU Desa diatur pula melalui Peraturan Pemerintah Nomor 43 Tahun 2014 tentang Pelaksanaan UU Desa dan Peraturan Menteri Desa, Pembangunan Daerah Tertinggal, dan Transmigrasi Nomor 4 Tahun 2015 tentang Pendirian, 
Pengurusan, dan Pengelolaan, dan pembubaran Badan Usaha Milik Desa ${ }^{8}$. PP Pelaksanaan UU Desa antara lain mengatur mengenai:

a. Organisasi pengelola BUM Desa yang terdiri atas penasihat dan pelaksana operasional (Pasal 132);

b. Modal BUM Desa yang terdiri dari penyertaan modal Desa dan penyertaan modal masyarakat Desa (Pasal 135);

c. Anggaran Dasar dan Anggaran Rumah Tangga BUM Desa. Anggaran dasar memuat paling sedikit nama, tempat kedudukan, maksud dan tujuan, modal, kegiatan usaha, jangka waktu berdirinya BUM Desa, organisasi pengelola, serta tata cara penggunaan dan pembagian keuntungan. Adapun Anggaran rumah tangga memuat paling sedikit hak dan kewajiban, masa bakti, tata cara pengangkatan dan pemberhentian personel organisasi pengelola, penetapan jenis usaha, dan sumber modal (Pasal 136);

d. Pengembangan Kegiatan Usaha. Dalam rangka untuk mengembangkan kegiatan usahanya, BUM Desa dapat: a. menerima pinjaman dan/atau bantuan yang sah dari pihak lain; dan b. mendirikan unit usaha BUM Desa (Pasal 137);

e. Kepailitan BUM Desa (Pasal 140); dan

f. Pembentukan BUM Desa bersama. Dalam rangka kerja sama antar-Desa, 2 (dua) Desa atau lebih dapat membentuk BUM Desa bersama. Adapun Pembentukan BUM Desa dapat dilakukan melalui pendirian, penggabungan, atau peleburan BUM Desa (Pasal 142).

Materi muatan Permendes Nomor 4 Tahun 2015 terdiri dari 35 Pasal. Peraturan ini memberikan panduan tentang tata cara Pendirian, Pengurusan dan Pengelolaan, dan Pembubaran Badan Usaha Milik Desa. Pasal 2 peraturan ini mengatur bahwa pendirian BUMdesa dimaksudkan sebagai upaya menampung seluruh kegiatan di bidang ekonomi dan/atau pelayanan umum yang dikelola oleh Desa dan/atau kerjasama antar-Desa. Pasal 4 ayat (2) mengatur bahwa Desa dapat mendirikan BUM Desa dengan mempertimbangkan:

a. Inisiatif Pemerintah Desa dan/atau masyarakat Desa;

b. Potensi usaha ekonomi Desa;

c. Sumberdaya alam di Desa;

d. Sumberdaya manusia yang mampu mengelola Bum Desa; dan

e. Penyertaan modal dari Pemerintah Desa dalam bentuk pembiayaan dan kekayaan Desa yang diserahkan untuk dikelola sebagai bagian dari usaha BUMDesa.

Selain itu, Pasal 7 dan Pasal 8 mengatur terkait Bentuk Organisasi BUMDesa. Pasal 9 sampai Pasal 16 mengatur terkait Organisasi Pengelola BUMDesa. Pasal 17 dan Pasal 18 mengatur terkait ketentuan modal BUMDesa. Peraturan ini juga mengatur terkait pembinaan dan pengawasan terkait manajemen BUMDesa. Dalam Permendes Nomor 4 Tahun 2015 terdapat klasifikasi jenis usaha yang dapat dikembangkan oleh BUMDesa, antara lain:

Jenis Usaha Dalam BUM Desa

\begin{tabular}{|c|c|c|c|}
\hline Pasal & $\begin{array}{c}\text { Klasifikasi } \\
\text { Jenis Usaha }\end{array}$ & Orientasi & Unit Usaha \\
\hline $\begin{array}{l}\text { Pasal } \\
19\end{array}$ & $\begin{array}{c}\text { bisnis sosial } \\
\text { (social } \\
\text { business) } \\
\text { sederhana }\end{array}$ & $\begin{array}{l}\text { memberikan } \\
\text { pelayanan umum } \\
\text { (serving) kepada } \\
\text { masyarakat dengan } \\
\text { memperoleh }\end{array}$ & $\begin{array}{l}\text { a. air minum Desa; } \\
\text { b. usaha listrik Desa; } \\
\text { c. lumbung pangan; dan } \\
\text { d. sumber daya lokal dan teknologi tepat } \\
\text { guna lainnya }\end{array}$ \\
\hline
\end{tabular}

${ }^{8}$ Peraturan Menteri ini dimaksudkan untuk melaksanakan ketentuan Pasal 142 Peraturan Pemerintah Nomor 43 Tahun 2014 tentang Peraturan Pelaksanaan Undang-Undang Nomor 6 Tahun 2014 tentang Desa. 


\begin{tabular}{|c|c|c|c|}
\hline & & $\begin{array}{l}\text { keuntungan } \\
\text { finansial }\end{array}$ & \\
\hline $\begin{array}{l}\text { Pasal } \\
20\end{array}$ & $\begin{array}{l}\text { bisnis } \\
\text { penyewaan } \\
\text { (renting) } \\
\text { barang }\end{array}$ & $\begin{array}{l}\text { untuk melayani } \\
\text { kebutuhan } \\
\text { masyarakat Desa } \\
\text { dan ditujukan untuk } \\
\text { memperoleh } \\
\text { Pendapatan Asli } \\
\text { Desa }\end{array}$ & $\begin{array}{l}\text { a. alat transportasi; } \\
\text { b. perkakas pesta; } \\
\text { c. gedung pertemuan; } \\
\text { d. rumah toko; } \\
\text { e. tanah milik BUM Desa; dan barang }\end{array}$ \\
\hline $\begin{array}{l}\text { Pasal } \\
21\end{array}$ & $\begin{array}{c}\text { usaha } \\
\text { perantara } \\
\text { (brokering) }\end{array}$ & $\begin{array}{l}\text { memberikan jasa } \\
\text { pelayanan kepada } \\
\text { warga. }\end{array}$ & $\begin{array}{l}\text { a. jasa pembayaran listrik; } \\
\text { b. pasar Desa untuk memasarkan produk } \\
\text { yang dihasilkan masyarakat; dan jasa } \\
\text { pelayanan lainnya }\end{array}$ \\
\hline $\begin{array}{l}\text { Pasal } \\
22\end{array}$ & $\begin{array}{c}\text { bisnis yang } \\
\text { berproduksi } \\
\text { dan/atau } \\
\text { berdagang } \\
\text { (trading) } \\
\text { barang-barang } \\
\text { tertentu }\end{array}$ & $\begin{array}{l}\text { untuk memenuhi } \\
\text { kebutuhan } \\
\text { masyarakat } \\
\text { maupun dipasarkan } \\
\text { pada skala pasar } \\
\text { yang lebih luas. }\end{array}$ & $\begin{array}{l}\text { a. pabrik es; b. pabrik asap cair; c. hasil } \\
\text { pertanian; d. sarana produksi pertanian; e. } \\
\text { sumur bekas tambang; dan f. kegiatan bisnis } \\
\text { produktif lainnya. }\end{array}$ \\
\hline $\begin{array}{l}\text { Pasal } \\
23\end{array}$ & $\begin{array}{l}\text { bisnis } \\
\text { keuangan } \\
\text { (financial } \\
\text { business) }\end{array}$ & $\begin{array}{l}\text { memenuhi } \\
\text { kebutuhan usaha- } \\
\text { usaha skala mikro } \\
\text { yang dijalankan } \\
\text { oleh pelaku usaha } \\
\text { ekonomi Desa. }\end{array}$ & $\begin{array}{l}\text { Unit usaha dalam BUM Desa dapat } \\
\text { memberikan akses kredit dan peminjaman } \\
\text { yang mudah diakses oleh masyarakat Desa. }\end{array}$ \\
\hline $\begin{array}{l}\text { Pasal } \\
24\end{array}$ & $\begin{array}{c}\text { usaha bersama } \\
\text { (holding) }\end{array}$ & $\begin{array}{l}\text { sebagai induk dari } \\
\text { unit-unit usaha } \\
\text { yang } \\
\text { dikembangkan } \\
\text { masyarakat Desa } \\
\text { baik dalam skala } \\
\text { lokal Desa maupun } \\
\text { kawasan perdesaan. }\end{array}$ & $\begin{array}{l}\text { Unit-unit usaha dapat berdiri sendiri yang } \\
\text { diatur dan dikelola secara sinergis oleh BUM } \\
\text { Desa agar tumbuh menjadi usaha bersama. Unit } \\
\text { usaha dalam BUM Desa dapat menjalankan } \\
\text { kegiatan usaha bersama meliputi: a. } \\
\text { pengembangan kapal Desa berskala besar } \\
\text { untuk mengorganisasi nelayan kecil agar } \\
\text { usahanya menjadi lebih ekspansif; b. } \\
\text { DesaWisata yang mengorganisir rangkaian } \\
\text { jenis usaha dari kelompok masyarakat; dan c. } \\
\text { kegiatan usaha bersama yang } \\
\text { mengkonsolidasikan jenis usaha lokal lainnya. }\end{array}$ \\
\hline
\end{tabular}

Dengan melihat konstruksi hukum di atas, maka BUM Desa ini diharapkan mampu menstimulasi dan menggerakkan roda perekonomian di pedesaan. Aset ekonomi yang ada di desa harus dikelola sepenuhnya oleh masyarakat desa. Substansi dan filosofi BUM Desa harus dijiwai dengan semangat kebersamaan dan self help sebagai upaya memperkuat aspek ekonomi 
kelembagaannya. Pada tahap ini, BUM Desa akan bergerak seirama dengan upaya meningkatkan sumber-sumber pendapatan asli desa, menggerakkan kegiatan ekonomi masyarakat ${ }^{9}$. Hal ini juga ditegaskan oleh Hardijono bahwa pendirian BUMDes merupakan jalan untuk membentuk ekonomi pedesaan yang mandiri sebagai upaya untuk meningkatkan Pendapatan Asli Daerah ${ }^{10}$.

Pengaturan mengenai BUM desa dalam UU Desa sudah komprehensif (terlebih juga terdapat Peraturan Pemerintah dan Peraturan Menteri Desa yang melengkapinya). UU Desa menjadi payung hukum utama terkait eksistensi BUM Desa. UU Desa sudah mengatur definisi, pendirian, pengelolaan, status hukum, fungsi, dan pemanfaatan hasil usaha BUM Desa, serta koordinasi Pemerintah Provinsi/Kab/Kota dengan Pemerintah Desa dalam hal pengelolaan BUM Desa. Pengaturan BUM Desa ini juga telah menegaskan keterkaitannya dengan Pancasila, yaitu bahwa BUM Desa dikelola dengan semangat kekeluargaan dan kegotongroyongan. Selain itu hasil usaha BUM Desa dapat digunakan untuk pengembangan usaha, pembangunan Desa, pemberdayaan masyarakat Desa, dan pemberian bantuan untuk masyarakat miskin melalui hibah, bantuan sosial, yang kesemuanya mencerminkan sila kelima Pancasila.

Pengaturan BUM Desa ini diatur dalam 3 (tiga) level peraturan perundang-undangan (Undang-Undang, Peraturan Pemerintah, dan Peraturan Menteri). Pengaturan yang sangat komprehensif justru diatur dalam level Peraturan Menteri. BUM Desa merupakan pilar dan tonggak yang dapat mendorong kemajuan desa sehingga hal-hal penting sudah seharusnya diatur dalam level Undang-Undang, seperti struktur pengelola BUM Desa dan pemodalan BUM Desa. Selain itu, pengaturan BUM Desa dalam UU Desa terkesan 'menyamaratakan' keberadaan semua desa. Padahal kondisi politik, sosial, dan budaya antar desa jelas berbeda-beda (ada pula desa adat) sehingga perlu diatur konsep pengelolaan BUM Desa secara asimetris. Selain itu keberadaan UU Nomor 11 Tahun 2020 tentang Cipta Kerja telah mengubah definisi BUM Desa. Hal ini akan berdampak pada status hukum keberadaan BUM Desa. Keberadaan BUM Desa yang selama ini sudah eksis tentu harus disesuaikan dengan UU Ciptaker.

\section{Kesesuaian Pengaturan Badan Usaha Milik Desa dengan Nilai-Nilai Pancasila}

Pengaturan BUM Desa dalam berbagai regulasi di atas secara normatif sudah berkesuaian dengan nilai-nilai Pancasila. Sila kemanusiaan, persatuan, kerakyatan, dan keadilan sudah dijadikan sebagai landasan dalam pendirian, pengelolaan, pengembangan, dan pemanfaatan hasil usaha BUM Desa.

\section{Nilai Persatuan Indonesia melalui Prinsip Kekeluargaan dan Kegotongroyongan dalam mengelola BUM Desa}

Nilai "Persatuan Indonesia" sebagaimana dijelaskan dalam penjelasan resmi Pembukaan UUD NRI Tahun 1945 yang termuat dalam Berita Republik Indonesia Tahun ke II, No.7, bahwa mendirikan negara Indonesia, digunakan aliran pengertian "Negara Persatuan" yaitu negara mengatasi segala paham golongan dan paham perseorangan, jadi bukan negara berdasar individualisme, dan juga bukan negara yang mengutamakan klass staat (negara klasa) yang mengutamakan satu golongan. Maka negara Indonesia adalah negara yang berdasarkan asas kekeluargaan, tolong menolong, menolong atau dengan dasar keadilan sosial. Maka dapat dipahami bahwa tujuan mendirikan negara Indonesia antara lain adalah mengutamakan seluruh bangsa

${ }^{9}$ Coristya Berlian Ramadana, Heru Ribawanto, Suwondo, "Keberadaan Badan Usaha Milik Desa (BUMDES) Sebagai Penguatan Ekonomi Desa (Studi di Desa Landungsari, Kecamatan Dau, Kabupaten Malang)", Jurnal Administrasi Publik (JAP), Vol. 1, No. 6, hlm. 1069.

${ }^{10}$ Edy Yusuf Agunggunanto, Fitrie Arianti Edi Wibowo Kushartono, Darwanto, Pengembangan Desa Mandiri Melalui Pengelolaan Badan Usaha Milik Desa (BUMDes)", Jurnal Dinamika Ekonomi dan Bisnis Unisnu Jepara, Vol.13, No.1, Maret 2016. 
Indonesia $^{11}$. Jiwa persatuan melalui gotongroyong inilah yang kemudian dapat dijadikan sebagai nilai dalam menghasilkan kebijakan terutama dalam mengelola Desa khususnya BUM Desa.

Dalam UU Desa ditegaskan bahwa BUM Desa dikelola dengan semangat kekeluargaan dan kegotongroyongan. Dalam penjelasan UU Desa, nilai kekeluargaan merupakan kebiasaan warga masyarakat Desa sebagai bagian dari satu kesatuan keluarga besar masyarakat Desa, sedangkan nilai kegotongroyongan yaitu kebiasaan saling tolong-menolong untuk membangun Desa. Artinya sejak awal pengelolaan BUM Desa sudah dikonstruksikan harus dilakukan berdasarkan kekeluargaan dan kegotongroyongan.

\section{Nilai Kerakyatan melalui Prinsip Musyawarah dalam mendirikan BUM Desa}

Pendirian BUM Desa disepakati melalui Musyawarah Desa dan ditetapkan dengan Peraturan Desa. Adanya musyawarah desa ini memungkinkan berlangsungnya proses pengambilan keputusan yang menyangkut kepentingan masyarakat Desa melalui diskusi dengan berbagai pihak yang berkepentingan.

Adanya partisipasi masyarakat dalam penyelenggaraan pemerintahan desa ini juga merupakan wujud dari kehidupan masyarakat desa yang merupakan bentuk komunitas yang dapat mengurus dirinya sendiri. ${ }^{12}$ Nilai musyawarah ini penting dan berkaitan dengan sila keempat Pancasila. Adapun Pemahaman mengenai sila keempat, Pancasila pada pelaksanaannya tidak dapat dipisahkan antara sila yang satu dengan sila-sila yang lainnya. Lebih jauh lagi, para bapak pendiri negara Indonesia merumuskan dasar hukum musyawarah tidak hanya pada tingkat nasional akan tetapi juga pelaksanaan musyawarah sebagai sistem pemerintahan baik pada tingkat pusat maupun daerah $^{13}$.

\section{Nilai Kemanusiaan dan Keadilan melalui Pemanfaatan Hasil Usaha BUM Desa yang mencerminkan Prinsip Ekonomi Pancasila}

Hasil usaha dari BUM Desa digunakan untuk pengembangan usaha, pembangunan Desa, pemberdayaan masyarakat Desa, dan pemberian bantuan untuk masyarakat miskin melalui hibah, bantuan sosial, dan kegiatan dana bergulir yang ditetapkan dalam Anggaran Pendapatan dan Belanja Desa. Pengaturan yang demikian mencerminkan prinsip Ekonomi Pancasila sebagaimana tertuang dalam UUD NRI 1945. Adapun Menurut Mubyarto Pasal 33 UUD NRI 1945 mencerminkan nilai ekonomi kekeluargaan yaitu ekonomi yang demokratis, dimana kemakmuran masyarakat lebih diutamakan ketimbang kemakmuran orang-seorang. Dan cita-cita melaksanakan ekonomi yang demikian adalah melalui sistem ekonomi koperasi, ekonomi betdasar kerjasama bukan ekonomi yang betdasar persaingan bebas ${ }^{14}$.

BUM Desa yang hasilnya diarahkan pada pemberdayaan masyarakat dan membantu masyarakat miskin merupakan implementasi dari Sila Keadilan Sosial. Jika ditarik kebelakang, rumusan sila kelima tersebut merupakan hasil perumusan Panitia Sembilan yang ditahbiskan dari prinsip kesejahteraan yang disebut sebagai prinsip keempat dari pidato Soekarno pada tanggal 1 Juni 1945. ${ }^{15}$ Selain Sila Pancasila tersebut, Pembukaan UUD NRI 19451945 sendiri memberikan perhatian istimewa terhadap masalah keadilan, sedemikian rupa sehingga kata "keadilan/adil" dan prinsip keadilan hampir ada disemua alenia. Khususnya dalam alenia keempat yang merupakan tujuan negara yaitu untuk memajukan "kesejahteraan umum" (yang mengandung prinsip

${ }^{11}$ Hanafi, Hakekat Nilai Persatuan Dalam Konteks Indonesia (Sebuah Tinjauan Kontekstual Positif Sila Ketiga Pancasila), JIPPK, Volume 3, Nomor 1, hlm.59.

12 Jimly Asshiddiqie, Pengantar Ilmu ...Op.Cit, hlm. 179.

${ }^{13}$ Muhammad Hanafi, Kedudukan Musyawarah dan Demokrasi di Indonesia, Jurnal Cita Hukum Vol.1. No.2, Desember 2013, hlm. 241.

${ }^{14}$ Mubyarto, Ekonomi Pancasila, Pusat Studi Ekonomi Pancasila, UGM, 2003, hlm.10.

${ }^{15}$ Yudi Latif, Negara Paripurna: HIstoritas, Rasionalitas, dan Aktualitas Pancasila, Gramedia Pustaka Utama, Jakarta, 2011, hlm. 533. 
keadilan). ${ }^{16}$ Lebih lanjut dalam Pembukaan UUD NRI Tahun 1945 yang menyebutkan bahwa "negara hendak mewujudkan keadilan sosial bagi seluruh rakyat Indonesia" mengandung pokok pikiran bahwa Indonesia mempunyai hak dan kewajiban yang sama untuk menciptakan keadilan sosial dalam kehidupan masyarakat. ${ }^{17}$ Prinsip keadilan sosial dari Pembukaan ini meliputi suasana kebatinan perumusan pasal-pasal UUD dan dokumen lain yang terkait dengan itu -yang bisa dijadikan sebagai sumber hukum dasar yang tidak tertulis. Jaminan keadilan/kesejahteraan tersebutlah yang melahirkan kewajiban pemerintah untuk memajukan kesejahteraan umum yang juga merupakan ciri negara kesejahteraan. Sebagaimana telah disebutkan sebelumnya, Indonesia tergolong sebagai negara kesejahteraan karena tugas pemerintah tidaklah semata-mata hanya di bidang pemerintahan saja, melainkan harus juga melaksanakan kesejahteraan sosial dalam rangka mencapai tujuan negara, yang dijalankan melalui pembangunan nasional. ${ }^{18}$

BUM Desa sebagai kekuatan perekonomian baru di desa mempunyai peran ganda, baik sebagai lembaga komersial yang bertujuan untuk meningkatkan Pendapatan Asli Desa (PAD) maupun sebagai lembaga sosial yang berpihak kepada masyarakat melalui usaha-usaha ekonomi yang berbasiskan pemberdayaan. Kegiatan pemberdayaan berarti kegiatan untuk menjadikan masyarakat lebih berdaya sebagai komunitas.

Berdasarkan uraian di atas, maka keberadaan UU Desa beserta peraturan turunannya yang mengatur mengenai BUM Desa, telah berkesuaian dengan Pancasila dan akan berdampak positif pada empat hal sebagai berikut:

a. memberikan kepastian hukum bagi pemerintah desa dalam melakukan aktifitas usaha milik desa;

b. mewujudkan pelembagaan usaha milik Desa dalam rangka percepatan kinerja unit usaha milik desa;

c. mengembangkan potensi ekonomi yang dimiliki oleh Desa dalam rangka mewujudkan kesejahteraan masyarakat Desa; dan

d. mendorong partisipasi masyarakat Desa dalam pengelolaan unit usaha milik Desa.

Adapun meski secara normatif pengaturan BUM Desa telah berkesesuaian dengan nilai Pancasila, terdapat berbagai tantangan yang harus segera diatasi terkait implementasi keberadaaan BUM Desa, seperti kapasitas Sumber Daya Manusia pengelola BUM Desa yang belum merata, perwujudan konsep transparansi dan akuntabilitas dalam pengelolaan keuangan BUM Desa, ketepatan sasaran dalam pembentukan unit usaha dalam BUM Desa, dan profesionalitas pengelolaan BUM Desa yang diarahkan pada pemberdayaan masyarakat.

Disisi lain, apabila BUM Desa dijalankan dengan baik oleh Pemerintah dan Masyarakat Desa, konsep pemanfaatan hasil usaha yang beorientasi pada pemberdayaan dan kesejahteraan masyarakat Desa dapat terwujud. Selain itu, struktur kepengurusan BUM Desa diutamakan penduduk desa setempat sehingga dapat pemberdayaan masyarakat pun juga dapat terwujud. Jenis dan klasifikasi usaha BUM Desa juga dapat disesuaikan dengan potensi ekonomi desa. Disisi lain terdapat kewajiban bagi Pemerintah, Pemerintah Provinsi, Pemerintah Kabupaten/Kota untuk melakukan pembinaan yang dilakukan melalui program menyusun dan memfasilitasi petunjuk teknis bagi BUM Desa. Khusus Pemerintah Kabupaten/Kota dapat pula melaksanakan peningkatan kapasitas BUM Desa.

\section{KESIMPULAN DAN SARAN}

Berdasarkan analisis pembahasan di atas, kesimpulan dalam penelitian ini adalah sebagai berikut. Pertama, Pengaturan BUM Desa diatur dalam 3 (tiga) level peraturan perundang-undangan (Undang-Undang, Peraturan Pemerintah, dan Peraturan Menteri). Pengaturan yang sangat komprehensif justru diatur dalam level Peraturan Menteri. BUM Desa merupakan pilar dan tonggak yang dapat mendorong kemajuan desa sehingga hal-hal penting sudah seharusnya diatur dalam level

\footnotetext{
${ }^{16}$ Ibid.

${ }^{17}$ NI'matul Huda, UUD 1945 dan Gagasan Amandemen Ulang, Rajawali Pers, Jakarta, 2008, hlm. 127.

${ }^{18}$ Ridwan HR, Diskresi dan Tanggungjawab Pemerintah, FH UII Press, Yogyakarta, 2014, hlm. 3.
} 
Undang-Undang, seperti struktur pengelola BUM Desa dan pemodalan BUM Desa. Semua regulasi yang mengatur mengenai BUM desa perlu dilakukan sinkronisasi dan harmonisasi. Kedua, Pengaturan BUM Desa dalam berbagai regulasi secara normatif sudah berkesuaian dengan nilainilai Pancasila yaitu Sila kemanusiaan, persatuan, kerakyatan, dan keadilan sudah dijadikan sebagai landasan dalam pendirian, pengelolaan, pengembangan, dan pemanfaatan hasil usaha BUM Desa.

Adapun saran dalam penelitian ini, ke depan perlu membentuk sistem keuangan BUM Desa yang transparan dan akuntabel disamping peningkatan kapasitas SDM pengelola BUM Desa harus terus ditingkatkan. Kemudian perlunya pengaturan mengenai BUM Desa asimetris, mengingat bahwa antar desa satu dengan yang lainnya memiliki kondisi politik, sosial, ekonomi, dan budaya masing-masing. Selain itu perlunya sinergi dan koordinasi yang berkesinambungan antara Pemerintah, Pemerintah Provinsi, dan Pemerintah Kabupaten/Kota dengan Pemerintah Desa dalam pengelolaan dan pengembangan BUM Desa.

\section{REFERENSI}

\section{Perundang-Undangan}

Undang-Undang nomor 6 Tahun 2014 tentang Desa

Undang-Undang Nomor 11 Tahun 2020 tentang Cipta Kerja

Peraturan Pemerintah Nomor 43 Tahun 2014 tentang Pelaksanaan Undang-Undang Nomor 6 Tahun 2014 tentang Desa

Peraturan Menteri Desa, Pembangunan Daerah Tertinggal, dan Transmigrasi Nomor 4 Tahun 2015 tentang Pendirian, Pengurusan, dan Pengelolaan, dan pembubaran Badan Usaha Milik Desa.

Ateng Syafrudin dan Suprin Na'a, Republik Desa, Pergulatan Hukum Tradisional dan Hukum Modern dalam Desain Otonomi Daerah, Alumni, Bandung, 2010.

Coristya Berlian Ramadana, Heru Ribawanto, Suwondo, "Keberadaan Badan Usaha Milik Desa (BUMDES) Sebagai Penguatan Ekonomi Desa (Studi di Desa Landungsari, Kecamatan Dau, Kabupaten Malang)", Jurnal Administrasi Publik (JAP), Vol. 1, No. 6.

Edy Yusuf Agunggunanto, Fitrie Arianti Edi Wibowo Kushartono, Darwanto, Pengembangan Desa Mandiri Melalui Pengelolaan Badan Usaha Milik Desa (BUMDes)", Jurnal Dinamika Ekonomi dan Bisnis Unisnu Jepara, Vol.13, No.1, Maret 2016.

Hanafi, Hakekat Nilai Persatuan Dalam Konteks Indonesia (Sebuah Tinjauan Kontekstual Positif Sila Ketiga Pancasila), JIPPK, Volume 3, Nomor 1.

https://www.wartaekonomi.co.id/read231487/mendorong-pengelolaan-bumdesa-secaraprofesional (diakses 13 April 2021)

Jimly Ashhiddiqie, Konstitusi Dan Konstitusionalisme Indonesia, Sinar Grafika, Jakarta, 2011.

Jimly Asshiddiqie, Pengantar Ilmu Hukum Tata Negara. Cet 3, Rajawali Press, Jakarta, 2011.

Kementerian Desa, Pembangunan Daerah Tertinggal dan Transmigrasi Republik Indonesia, Modul KKN Tematik Desa Membangun Badan Usaha Milik Desa (BUM Desa), Jakarta, 2019.

Mubyarto, Ekonomi Pancasila, Pusat Studi Ekonomi Pancasila, UGM, 2003.

Muhammad Hanafi, Kedudukan Musyawarah dan Demokrasi di Indonesia, Jurnal Cita Hukum Vol.1. No.2, Desember 2013.

Ni'matul Huda, Hukum Pemerintahan Desa Dalam Konstitusi Indonesia Sejak Kemerdekaan Hingga Era Reformasi, Setara Press, Malang, 2015.

Ni'matul Huda, UUD 1945 dan Gagasan Amandemen Ulang, Rajawali Pers, Jakarta, 2008.

Ridwan HR, Diskresi dan Tanggungjawab Pemerintah, FH UII Press, Yogyakarta, 2014.

Sri Hastuti Puspitasari, Menuju Kemandirian Desa Melalui Undang-Undang Nomor 6 Tahun 2014 Tentang Desa, FH UII, Yogyakarta, 2017

Yudi Latif, Negara Paripurna: HIstoritas, Rasionalitas, dan Aktualitas Pancasila, Gramedia Pustaka Utama, Jakarta, 2011. 


\section{Competing interests}

No conflict interest.

\section{Funding.}

None.

\section{Acknowledgements.}

Thank you to all those who have supported and helped this research.

\section{About the Authors}

The author is a Lecture at Universitas Islam Indonesia. 